\title{
Airborne Measurements of Ozone and Its Precursors over Yeosu-Gwangyang Industrial Areas in the Southern Coast of Korea
}

\author{
So-young Kim*, Seok-jun Seo, Hyun-ju Park, Jung-seok Son, Ji- hoon Park and Jong-choon Kim \\ Air Quality Research Division, National Institute of Environmental Research Kyungseo-dong, Seo-gu, Incheon 404-708, Korea \\ *Corresponding author. Tel: +82-32-560-7276, E-mail: air3500@korea.kr
}

\begin{abstract}
The purpose of this study is to understand distributional characteristics in the atmospheric concentrations of $\mathrm{O}_{3}$ and its precursors based on data taken at the southern Korean coast. The average $\mathrm{O}_{3}$ concentration in the high altitude was found to range from 32.3 to $90.8 \mathrm{ppb}$ with a maximum concentration of $132 \mathrm{ppb}$. The ambient $\mathrm{O}_{3}$ concentration was high at altitudes of $1000 \mathrm{~m}$ and $500 \mathrm{~m}$ above the southern sea near Gwangyang Bay and an industrial area containing emission sources. The daily mean concentrations of $\mathrm{NO}_{y}$ and $\mathrm{CO}$ were 6.7-24.2 ppb and 0.152$0.487 \mathrm{ppm}$, respectively. During the aerial measurement period, the highest mean concentration of $\mathrm{O}_{3}$ was observed on June 1 . The aerial measurement results showed that the maximum ozone concentration was observed to be $132 \mathrm{ppb}$ in the high altitude the southernmost part of Yeosu. The measurement of vertical wind fields in the air indicated that $\mathrm{O}_{3}$ formed in the southernmost part of Yeosu was transported by strong southwesterly winds to the northeast of Gwangyang Bay. This led to a ground $\mathrm{O}_{3}$ concentration of over $100 \mathrm{ppb}$ in Jinju, the northeastern part of Gwangyang Bay. On August 9, when the maximum $\mathrm{O}_{3}$ concentration was $50 \mathrm{ppb}$, the measurement results showed that $\mathrm{O}_{3}$ concentrations were relatively low compared to other days. In particular, low $\mathrm{NO}_{2}$ and TVOC concentrations were observed, both of which serve to form $\mathrm{O}_{3}$ in photochemical reactions.
\end{abstract}

Key words: $\mathrm{O}_{3}, \mathrm{NO}_{2}$, TVOC, Gwangyang Bay, Photochemical reactions, Wind

\section{INTRODUCTION}

Ozone in the stratosphere serves as a protective shield for plants, animals, and humans on earth by absorbing $95 \%$ to $99 \%$ of the sun's harmful ultraviolet rays. The recently increasing levels of ozone in the troposphere, however, have been known to not only affect human health by irritating the eyes and respiratory system, but also do harm to crops (Papayannis et al., 1998; Herman et al., 1996). Tropospheric ozone is mainly formed from the reaction of volatile organic compounds (VOCs) and nitrogen oxides $\left(\mathrm{NO}_{\mathrm{x}}\right)$ under strong sunlight with almost no wind (Chameides et al., 1992; Fehsenfeld et al., 1992). In urban areas, where many sources of $\mathrm{NO}_{\mathrm{x}}$ and VOCs exist, the amount of ozone generation fluctuates widely due to photochemical reactions, transportation, and accumulation (Wang et al., 2001; Kleinman et al., 2000).

Gwangyang Bay, the site for this study, has an eastwest length of $27 \mathrm{~km}$ and a north-south length of 15 $\mathrm{km}$. It is surrounded by areas such as Gwangyang, Suncheon, Yeosu, Namhae, and Hadong. About 2.9 billion tons of fresh water flows to this narrow back bay from the Seomjin River every year. Gwangyang Bay is also a major industrial hub where large operations, including power plants, petrochemical complexes, and steel mills, are concentrated. In coastal areas such as Gwangyang Bay, the circulation between land and sea breeze typically affects ozone, and the wind direction is related to ozone accumulation (Cheng, 2002; Liu et al., 1992). This leads to frequent instances in which air quality standards are exceeded, despite proper awareness and control of air pollution.

Data on ozone warning in Gwangyang Bay during a six-year period from 2003 to 2008 were compared with data from metropolitan areas including Seoul, Incheon, and Gyeonggi. It was found that Gwangyang Bay issued ozone warnings more frequently than those metropolitan cities inhabited by more than 20 million people. Yeosu, Suncheon and Gwangyang issued ozone warnings five times in 2006 and 22 times in 2007. This indicates that photochemical pollution in these areas was significantly higher than 
in other parts of Korea.

The high-ozone episodes in the Gwangyang Bay area were usually observed in summer. Many studies into the causes of highly-concentrated ozone have been performed in Korea and abroad. According to a study conducted by the National Institute of Environmental Research (NIER) in 2006 to identify the generation of photochemical air pollutants, the main factors influencing ozone occurrence include temperature, solar radiation, cloudiness, and wind speed. It was found that in similar weather, higher concentrations of $\mathrm{NO}_{\mathrm{x}}$ and VOCs create more favorable conditions for highly-concentrated ozone. In addition, a study conducted in Busan, a coastal area like Gwangyang Bay, showed that higher ozone concentrations and more frequent high-ozone episodes were observed during the early afternoon when sea breeze are usually absent (Oh et al., 2004). The occurrence of ozone is not limited to the surface. The vertical transportation of ozone transferred from neighboring areas or produced from mixed layers is known to have a significant influence as well. Thus, the characteristics of its vertical distribution and advection have also been studied (Lee et al., 2009; Helmig et al., 2002). In Korea, many studies on Gwangyang Bay ozone (Ha et al., 2006) have focused on ground monitoring results, while almost no measurements have been made using aircraft in the larger area including Gwangyang Bay and its background areas. In this study, aircraft measurement were conducted for the spatial distribution of ozone and its precursors in Gwangyang Bay and neighboring areas to determine the distributional patterns at various latitudes, longitudes, and locations, and a comparative analysis was made of the spatial distributions.

\section{METHODS}

Various data were used to identify the spatial distribution of ozone and its precursors at the southern coast, including the results of aerial observations and ground monitoring and data on ground air and high altitude measured during the periods from May 25 to June 15, and July 25 to August 15, 2009.

For analysis, data were divided into two groups: high concentration days, on which the highest $\mathrm{O}_{3}$ concentration was observed (100 ppb or higher), and low concentration days, on which the highest $\mathrm{O}_{3}$ concentration was lower than $50 \mathrm{ppb}$. To analyze the aerial measurement results, a comparison was made between the aerial measurements and ground measurements, both of which were performed in the same time period. The concentration data used for this study

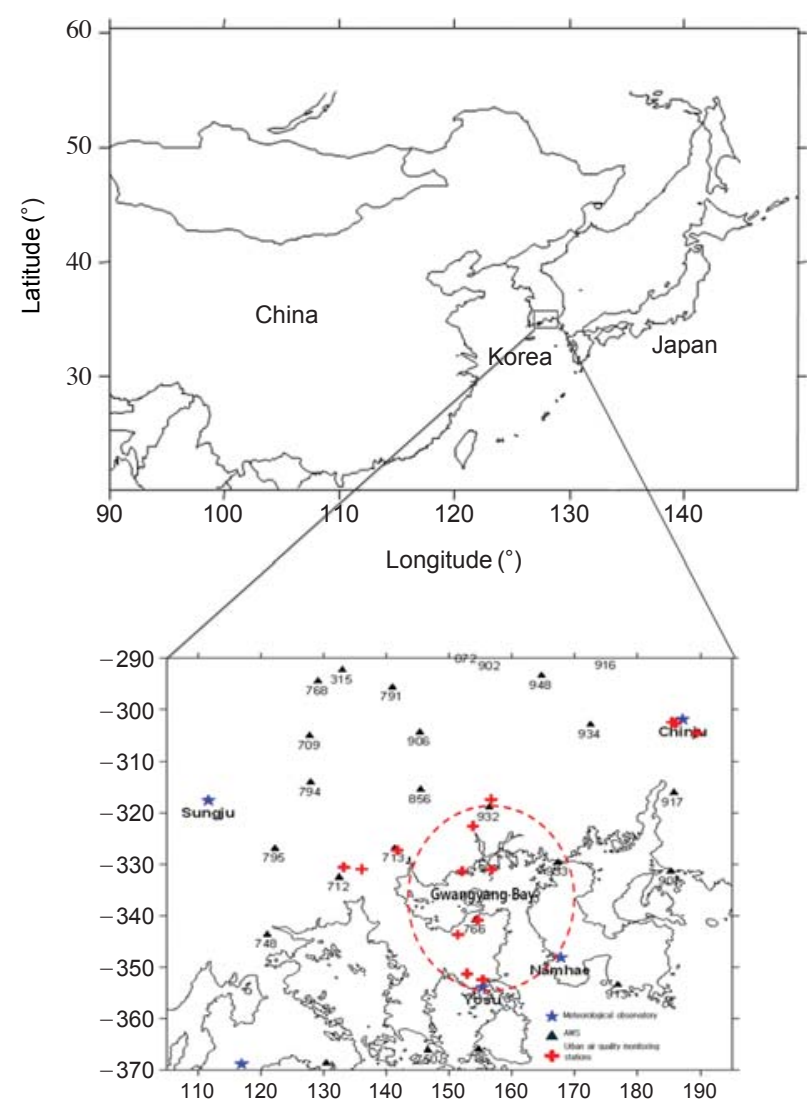

Fig. 1. Air quality monitoring stations and meteorological observatories around the study site.

were collected from a network of 14 stations air quality monitoring stations (Fig. 1): four stations in Gwangyang City (Jeong-dong, Jinsang-myeon, Chilseong-ri, and Taein-dong), four stations in Yeosu City (Gwangmu-dong, Munsu-dong, Samil-dong, and Wollaedong), two stations in Suncheon (Yeonhyang-dong and Jangcheon-dong), and four stations in Jinju (Daeandong, Sangbongdong-dong, Sangpyeong-dong, and Ha-dong). To see the air conditionsin each case, weather data were also collected from the nearest meteorological offices located in Yeosu, Suncheon, Jinju, and Tongyeong. For the high altitude, data from the meteorological office in Gwangju, Jeollanam-do were used.

\section{1 Aerial Measurement}

The aircraft used for this study was a Chieftain PA31-350 twin-engine propeller model (U.S. Piper) owned by Changwoon Aviation Co., Ltd. The aircraft specifications and the measuring method were based on Han et al., 2005.

The inside of the aircraft was equipped with a gas analyzer (a trace-level Thermo model for $\mathrm{NO}_{\mathrm{y}}, \mathrm{O}_{3}$, and $\mathrm{CO}$ ) and a Tedlar bag for VOCs. An automatic 
Table 1. Description of relevant instruments equipped on the aircraft.

\begin{tabular}{|c|c|c|c|c|}
\hline $\begin{array}{l}\text { Species } \\
\text { detected }\end{array}$ & Technique & Range & $\begin{array}{l}\text { Response } \\
\text { time }\end{array}$ & Precision \\
\hline $\mathrm{O}_{3}$ & $\begin{array}{l}\text { UV Photometric / TEI } \\
\text { (Trace Level 49C) }\end{array}$ & $<100 \mathrm{ppb}$ & $20 \sec (10 \mathrm{sec}$ ave. $)$ & $1 \mathrm{ppb}$ \\
\hline $\mathrm{NO}_{\mathrm{y}}$ & $\begin{array}{c}\text { Chemiluminescence / TEI } \\
\text { (Trace Level 42C) }\end{array}$ & $<100 \mathrm{ppb}$ & $60 \mathrm{sec}(10 \mathrm{sec}$ ave. $)$ & $0.05 \mathrm{ppb}$ \\
\hline $\mathrm{CO}$ & $\begin{array}{c}\text { NDIR / TEI } \\
\text { (Trace Level 48C) }\end{array}$ & $<10 \mathrm{ppm}$ & $60 \sec (10 \mathrm{sec}$ ave. $)$ & $0.04 \mathrm{ppm}$ \\
\hline PAN & PMT (GC-Luminol) & $30 \mathrm{ppt}$ & $3 \min$ & - \\
\hline $\mathrm{HNO}_{3}$ & Auto sampler / DI water & - & $5 \min$ & \\
\hline $\mathrm{SO}_{4}^{2-}$ & Auto sampler / DI water & - & $5 \mathrm{~min}$ & - \\
\hline VOCs & GC-FID / Perkin- Elmer & - & - & - \\
\hline
\end{tabular}

mass flow control system was installed on the gas analyzer to avoid any alteration to suction flow, which can happen with changes in flight altitude. Table 1 lists the measurement items used in the aircraft above the southern coast. The concentrations of $\mathrm{O}_{3}, \mathrm{NO}_{\mathrm{y}}$ and $\mathrm{CO}$ were measured consecutively. Before and after a measurement was performed, corrections to the instrument were made in the laboratory or field based on the installation conditions applied in the aircraft. The instrument was warmed up for two to three hours after beginning its operation. When it was stabilized, the zero gas was released to set background concentration values. An ozone generator made by the Korea Research Institute of Standards and Science (KRISS) was used to correct the concentration to 7 points or higher in the range of $0-200 \mathrm{ppbv}$. To measure VOCs, a precursor important to ozone generation, Teflon bags were used to collect samples at several selected points where VOC concentration levels could be observed. Every flight collected about ten samples. These samples were quickly transported to the laboratory and quantitatively analyzed with an ATD-GC/FID (Markes Unity, Varian 450GC/FID). For VOCs that could not be identified with the FID detector, an ATD-GC/MS (Markes Unity, Shimadzu GC17A/QP5050A) was used for qualitative analysis. In addition, PAN (peroxyacetyl nitrate), $\mathrm{HNO}_{3}$, and $\mathrm{SO}_{4}{ }^{2-}$, key photochemical indicators for evaluation of photochemical reactions and reaction paths, were measured as well. The chemiluminescence method was also applied, allowing the wavelength of $425 \mathrm{~nm}$ to appear strongly when PAN contacted luminol. In addition, measuring equipment using a PMT (photomultiplier) was built and employed. This method allowed for fast analysis (two minutes or less) at higher definitions than GC-ECD (Graffney et al., 1998). A liquid absorbent was used to sample the $\mathrm{HNO}_{3}$ and $\mathrm{SO}_{4}{ }^{2-}$. A system was created to consecutively store the samples in vials using a syringe that moved along the $\mathrm{X}$ -

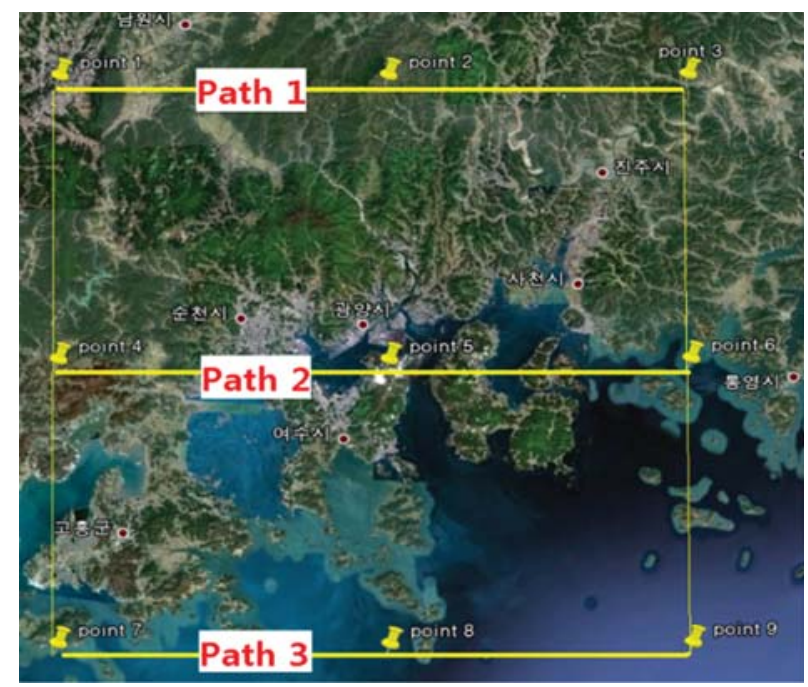

Fig. 2. Flight paths during the measurement period.

and Y-axes. The collected samples were transported to the laboratory for analysis with IC.

For more details regarding the measurement methods, refer to Seo et al., 2012. The main flight paths used for aerial measurement are detailed in Section 3.

\subsubsection{Aerial Observation Paths}

To analyze the spatial distribution of ozone and its precursors at the southern coast, weather charts and conditions of the upper and ground air were checked, and the ground ozone concentration was monitored before flight. The main flight paths are shown in Fig. 2. In addition, three paths that cross east to west in the Gwangyang Bay area were also selected as major paths for measurement. Path 1 was selected to observe the transport of ozone and its precursors that move along the sea breeze in Gwangyang Bay. Path 2, below which major sources are concentrated, was 
Table 2. Summary of flight track.

\begin{tabular}{lcccc}
\hline Flight paths & Point & Latitude & Longitude & Altitude $(\mathrm{m})$ \\
\hline Path 1 & Point 1 & $35^{\circ} 19^{\prime} \mathrm{N}$ & $127^{\circ} 10^{\prime} \mathrm{E}$ & 1000,1500 \\
$($ Point 1↔3) & Point 2 & $35^{\circ} 19^{\prime} \mathrm{N}$ & $127^{\circ} 44^{\prime} \mathrm{E}$ & 1000,1500 \\
& Point 3 & $35^{\circ} 19^{\prime} \mathrm{N}$ & $128^{\circ} 15^{\prime} \mathrm{E}$ & 1000,1500 \\
\hline Path 2 & Point 4 & $34^{\circ} 52^{\prime} \mathrm{N}$ & $127^{\circ} 10^{\prime} \mathrm{E}$ & 500,1000 \\
$($ Point 4↔6) & Point 5 & $34^{\circ} 52^{\prime} \mathrm{N}$ & $127^{\circ} 44^{\prime} \mathrm{E}$ & 500,1000 \\
& Point 6 & $34^{\circ} 52^{\prime} \mathrm{N}$ & $128^{\circ} 15^{\prime} \mathrm{E}$ & 500,1000 \\
\hline \multirow{2}{*}{ Path 3 } & Point 7 & $34^{\circ} 25^{\prime} \mathrm{N}$ & $127^{\circ} 10^{\prime} \mathrm{E}$ & 500,1000 \\
$($ Point 7↔9) & Point 8 & $34^{\circ} 25^{\prime} \mathrm{N}$ & $127^{\circ} 44^{\prime} \mathrm{E}$ & 500,1000 \\
& Point 9 & $34^{\circ} 25^{\prime} \mathrm{N}$ & $128^{\circ} 15^{\prime} \mathrm{E}$ & 500,1000 \\
\hline
\end{tabular}

Table 3. Meteorological condition at weather stations during the sampling period.

\begin{tabular}{lcccccccc}
\hline & Jun. 1 & Jun. 5 & Jul. 30 & Aug. 4 & Aug. 5 & Aug. 8 & Aug. 9 & Aug. 10 \\
\hline Mean Temp $\left({ }^{\circ} \mathrm{C}\right)$ & 20.0 & 20.3 & 24.1 & 24.0 & 24.8 & 25.9 & 25.9 & 25.9 \\
Max Temp $\left({ }^{\circ} \mathrm{C}\right)$ & 26.7 & 26.3 & 29.7 & 29.1 & 29.4 & 31.0 & 29.1 & 29.7 \\
RH $(\%)$ & 65.0 & 76.3 & 79.2 & 75.5 & 68.8 & 80.1 & 76.1 & 77.2 \\
Sunshine $(\mathrm{hr})$ & 11.8 & 8.6 & 6.9 & 7.2 & 9.7 & 6.4 & 3.7 & 0.8 \\
Wind speed $(\mathrm{m} / \mathrm{s})$ & 2.2 & 1.6 & 1.3 & 1.8 & 2.3 & 1.8 & 2.6 & 2.1 \\
Cloud cover & 1.2 & 5.1 & 5.7 & 6.5 & 3.9 & 5.9 & 6.7 & 9.3 \\
\hline
\end{tabular}

chosen to monitor the release and distribution of ozone and its precursors from theYeosu Industrial Complex and steel mills. Path 3 was selected to survey the generation and transport of ozone and its precursors above the sea. The standard flight altitudeswere set at $500 \mathrm{~m}$ and $1,000 \mathrm{~m}$. For Path 1, however, $1,000 \mathrm{~m}$ and $1,500 \mathrm{~m}$ were used as standards due to the geographical restrictions of the mountainous terrain. More information on the paths is shown in Table 2.

\section{2 Measuring the High Altitude}

Pibal (pilot balloon) measurements were conducted to analyze more accurately how $\mathrm{O}_{3}$ spatial transportation associated with weather conditions affects the occurrence of high ozone concentrations on the ground. The site selected for this measurement was the playground of Sinheung Elementary School in Yeosu City, located southwest of the Yeosu Industrial Complex and Gwangyang Bay.

For the pibal measurement, a red balloon with a diameter of about $80 \mathrm{~cm}$ was injected with helium and floated into the air. On the ground, the azimuth and altitude angles of the balloon were measured every 30 seconds using a theodolite equipped with a telescope to check the wind direction and speed at each altitude. The speed at which the balloon rose was about $4 \mathrm{~m} / \mathrm{sec}$. Wind direction and speed in the high altitude were measured for about ten minutes.

The measurement was carried out four times a day. The measurement times were 08:00, 12:00, 17:00, and 21:00. These times sometimes changed slightly with weather conditions and air pollution states. The actual measurement time was based on the flight schedule, however, it was a priority to take measurements on time.

\section{RESULTS AND DISCUSSION}

\subsection{Analysis of Weather Conditions and Air Currents during the Measurement Period}

To track weather conditions on the ground during the periods of aerial measurement, data from meteorological offices located near the flight paths were used (Fig. 1). Also, the AWS data from six locations within the aerial measurement area, including Yeosu, Suncheon, Jinju, Tongyeong, Namhae, and Goheung, were used. The mean values of the data collected during the aerial observation days are listed in Table 3 . During the measurement period, the mean temperature was found to range from $20.0^{\circ} \mathrm{C}$ to $25.9^{\circ} \mathrm{C}$, while the highest temperature was $31.0^{\circ} \mathrm{C}$. The relative humidity was between $64 \%$ and $80 \%$. The mean wind speed was about $1-2 \mathrm{~m} / \mathrm{s}$.

Data were analyzed to investigate synoptic weather conditions during the aerial observation period, including $850 \mathrm{hPa}$ weather charts and satellite data for each measurement day provided by the Korea Meteorological Administration. In addition, a backward trajectory analysis was made during the same period to monitor the transport path of air currents in the Gwang- 

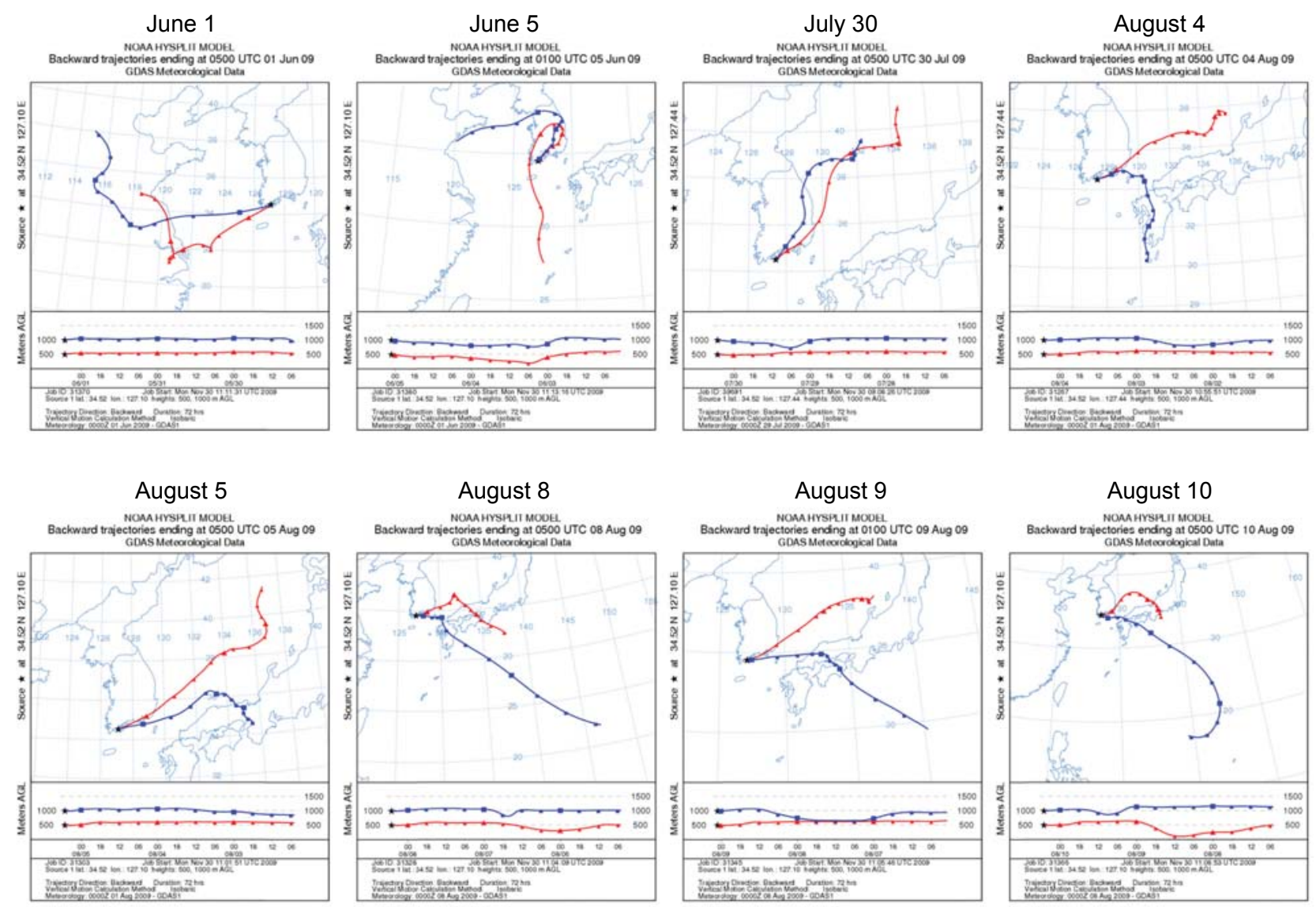

Fig. 3. $850 \mathrm{hPa}$ weather charts, satellite photographs and backward trajectory data during the sampling period.

yang Bay area. The HYSPLIT4 model developed by the U.S. National Oceanic and Atmospheric Administration (NOAA) was used for the backward trajectory analysis. NOAA's FNL (Final run at NCEP) was also used as weather data. The 72-hour backward trajectory analysis was carried out at altitudes of $500 \mathrm{~m}$ and $1,000 \mathrm{~m}$ at the halfway point of Path 2 . The results of this analysis (Fig. 3) are as follows: on June 1, air currents came through Hebei and Shandong, China, while in August, most currents moved through the East Sea or Japan due to Typhoon Morakot.

\subsection{Ozone and Its Precursors in the High Altitude in the Southern Coast}

Tables 4 and 5 show the mean concentrations of $\mathrm{O}_{3}$, $\mathrm{NO}_{\mathrm{y}}, \mathrm{CO}, \mathrm{VOCs}, \mathrm{PAN}, \mathrm{HNO}_{3}$, and $\mathrm{SO}_{4}{ }^{2-}$ measured daily in Yeosu and Gwangyang during the aerial observation period.

The mean concentration of ozone ranged between 32.3 and $90.8 \mathrm{ppb}$. August 9 was the only day that had its highest $\mathrm{O}_{3}$ concentration fall below $50 \mathrm{ppb}$. On the other hand, the days on which the highest $\mathrm{O}_{3}$ concentration was observed to be $100 \mathrm{ppb}$ or higher were
June 1, July 30, and August 4. On July 30, the $\mathrm{O}_{3}$ concentration reached $142.5 \mathrm{ppb}$, the highest during the entire measurement period. This was observed during movement from Point 7 to Point 4, which was not a main path. The highest concentration observed in the main paths was $132 \mathrm{ppb}$ at an altitude of $500 \mathrm{~m}$ in Path 3 on June 1 . The mean $\mathrm{O}_{3}$ concentration during the entire measurement period was $60.5 \mathrm{ppb}$, higher than that in the background air (43 ppb) (the 2008 Annual Report of Ambient Air Quality in Korea, 2009) and that in the metropolitan areas (Seoul, Incheon and Gyeonggi) (30 ppb) measured by ground monitoring stations during the same period. To compare the ground ozone concentration and the ozone distribution at each altitude, it will be necessary to include ground measurements conducted during the same periods of time covered in this study, and data on the vertical distribution of ozone using an ozonesonde. Data from ozone measurements in other countries includes a 2005 aerial measurement in Texas, a coastal area in the southern part of the United States that shows an ozone concentration ranging between 35 and $130 \mathrm{ppb}$ at an altitude 550 to 2,600 $\mathrm{m}$ (Luria et al., 2008). In this study, the 
Table 4. Summary of aircraft measurement data during the sampling period (I).

\begin{tabular}{|c|c|c|c|c|c|c|c|c|}
\hline \multicolumn{2}{|c|}{ Flight date } & $\begin{array}{l}\text { Flight path } \\
\text { (time) }\end{array}$ & $\begin{array}{l}\text { Altitude } \\
(\mathrm{m})\end{array}$ & $\begin{array}{c}\mathrm{O}_{3}(\mathrm{ppb}) \\
\text { mean (max) }\end{array}$ & $\begin{array}{l}\mathrm{NO}_{\mathrm{y}}(\mathrm{ppb}) \\
\text { mean }(\max )\end{array}$ & $\begin{array}{c}\mathrm{CO}(\mathrm{ppm}) \\
\text { mean }(\max )\end{array}$ & $\begin{array}{l}\text { Temp. } \\
\left({ }^{\circ} \mathrm{C}\right)\end{array}$ & $\begin{array}{l}\mathrm{RH} \\
(\%)\end{array}$ \\
\hline \multirow{3}{*}{\multicolumn{2}{|c|}{ Jun. 1}} & $13: 29-15: 20$ & & $90.8(132.0)$ & $24.2(48.5)$ & $0.487(0.733)$ & - & - \\
\hline & & Path $1(13: 37-14: 10)$ & 1000 & $83.2(97.3)$ & $23.0(28.8)$ & $0.540(0.662)$ & & \\
\hline & & Path $3(14: 42-15: 03)$ & 500 & $109.7(132.0)$ & $24.7(28.6)$ & $0.490(0.560)$ & & \\
\hline \multirow{7}{*}{ Jun. 5} & \multirow{4}{*}{$\mathbf{A M}$} & 10:37-12:27 & & $63.7(77.9)$ & $14.3(27.9)$ & $0.375(0.753)$ & $32.4(34.8)$ & $16.7(23.9)$ \\
\hline & & Path 1 (10:37-11:05) & 1500 & $58.9(69.9)$ & $11.4(15.9)$ & $0.584(0.753)$ & $30.4(30.6)$ & $19.4(23.9)$ \\
\hline & & Path $2(11: 16-11: 35)$ & 1000 & $66.1(69.8)$ & $16.6(27.9)$ & $0.376(0.428)$ & $31.9(32.6)$ & $18.6(20.7)$ \\
\hline & & Path $3(11: 45-12: 08)$ & 1000 & $66.4(74.9)$ & $13.6(19.1)$ & $0.244(0.323)$ & $33.7(34.1)$ & $14.4(17.5)$ \\
\hline & \multirow{3}{*}{ PM } & 14:42-16:25 & & $67.2(94.0)$ & $7.7(13.2)$ & $0.183(0.318)$ & $31.6(33.1)$ & $16.7(21.1)$ \\
\hline & & Path $3(15: 12-15: 31)$ & 1000 & $67.7(78.5)$ & $5.6(7.5)$ & $0.171(0.201)$ & $31.1(31.4)$ & $14.5(19.0)$ \\
\hline & & Path $2(15: 42-16: 25)$ & 1000 & $69.5(94.0)$ & $10.2(13.2)$ & $0.149(0.282)$ & $31.6(32.0)$ & $18.8(21.1)$ \\
\hline \multirow{5}{*}{ Jul. 30} & & $13: 28-15: 14$ & & $77.8(142.5)$ & $22.5(61.8)$ & $0.404(1.318)$ & $23.0(25.8)$ & $67.6(74.7)$ \\
\hline & & Path $2(13: 28-13: 40)$ & 500 & $66.1(74.0)$ & $27.6(61.8)$ & $0.592(1.275)$ & - & - \\
\hline & & Path $3(13: 49-14: 10)$ & 500 & $85.0(93.1)$ & $21.6(29.2)$ & $0.398(0.566)$ & $23.0(23.7)$ & $68.8(72.7)$ \\
\hline & & Path 2 (14:18-14:39) & 1000 & $64.0(76.4)$ & $21.7(37.3)$ & $0.393(1.318)$ & $23.5(25.6)$ & $67.0(74.5)$ \\
\hline & & Path $3(14: 48-15: 06)$ & 1000 & $76.7(92.7)$ & $18.5(21.0)$ & $0.269(0.305)$ & $21.8(22.5)$ & $68.6(74.7)$ \\
\hline \multirow{7}{*}{ Aug. 4} & & $13: 22-16: 35$ & & $62.5(118.3)$ & $13.8(69.1)$ & $0.402(1.457)$ & $22.4(25.6)$ & $63.8(77.0)$ \\
\hline & & Path $2(13: 22-13: 43)$ & 500 & $60.1(77.0)$ & $27.0(69.1)$ & $0.863(1.457)$ & $23.8(24.3)$ & $64.3(67.0)$ \\
\hline & & Path 3 (13:52-14:17) & 500 & $65.8(80.5)$ & $10.7(13.0)$ & $0.458(1.007)$ & $23.0(23.8)$ & $64.5(67.2)$ \\
\hline & & Path 2 (14:26-14:52) & 1000 & $59.2(74.0)$ & $16.4(63.0)$ & $0.390(0.541)$ & $20.9(25.2)$ & $70.9(76.4)$ \\
\hline & & Path $3(15: 01-15: 25)$ & 1000 & $47.2(63.2)$ & $7.2(8.2)$ & $0.218(0.236)$ & $21.9(22.8)$ & $58.7(64.2)$ \\
\hline & & Path $2(15: 33-16: 03)$ & 500 & $76.1(118.3)$ & $17.5(44.4)$ & $0.390(1.107)$ & $24.0(25.6)$ & $63.1(74.5)$ \\
\hline & & Path 1 (16:11-16:03) & 1500 & $51.8(62.7)$ & $8.0(11.2)$ & $0.192(0.292)$ & $20.0(23.9)$ & $60.0(77.0)$ \\
\hline \multirow{7}{*}{ Aug. 5} & & 12:47-15:51 & & $57.4(81.4)$ & $11.2(36.7)$ & $0.227(0.808)$ & - & - \\
\hline & & Path $2(12: 47-13: 11)$ & 500 & $57.1(68.6)$ & $19.6(36.7)$ & $0.291(0.511)$ & - & - \\
\hline & & Path $3(13: 20-13: 42)$ & 500 & $61.4(68.5)$ & $10.2(11.5)$ & $0.280(0.325)$ & - & - \\
\hline & & Path $2(13: 52-14: 16)$ & 1000 & $57.7(68.6)$ & $13.8(35.8)$ & $0.265(0.808)$ & - & - \\
\hline & & Path $3(14: 27-14: 45)$ & 1000 & $42.2(66.4)$ & $6.6(8.1)$ & $0.172(0.203)$ & - & - \\
\hline & & Path $2(14: 54-15: 19)$ & 500 & $64.8(75.8)$ & $11.9(23.9)$ & $0.222(0.693)$ & - & - \\
\hline & & Path $1(15: 31-15: 51)$ & 1500 & $47.0(51.4)$ & $6.4(7.8)$ & $0.161(0.196)$ & - & - \\
\hline \multirow{5}{*}{ Aug. 8} & & 14:41-16:55 & & $51.3(87.8)$ & $11.2(69.8)$ & $0.152(0.1$ & $25.0(28.1)$ & $66.9(77.8)$ \\
\hline & & Path $2(14: 41-15: 05)$ & 500 & $55.0(71.8)$ & $19.7(69.8)$ & $0.152(0.153)$ & $27.0(28.1)$ & $64.3(69.2)$ \\
\hline & & Path $3(15: 15-15: 35)$ & 500 & $60.3(82.7)$ & $9.4(11.5)$ & $0.152(0.152)$ & $25.4(25.9)$ & $67.1(70.4)$ \\
\hline & & Path $2(15: 48-16: 08)$ & 1000 & $44.7(53.0)$ & $10.5(19.4)$ & $0.152(0.152)$ & $24.1(24.3)$ & $64.6(68.3)$ \\
\hline & & Path $3(16: 21-16: 41)$ & 1000 & $42.2(49.8)$ & $7.0(7.7)$ & $0.153(0.153)$ & $23.6(24.5)$ & $71.2(77.8)$ \\
\hline \multirow{12}{*}{ Aug. 9} & \multirow{7}{*}{$\mathbf{A M}$} & 10:10-13:06 & & $32.3(43.4)$ & $6.7(46.8)$ & $0.354(2.138)$ & $22.9(26.3)$ & $66.9(91.8)$ \\
\hline & & Path 2 (10:10-10:32) & 500 & $24.9(27.6)$ & $11.0(46.8)$ & $0.885(2.138)$ & $24.0(24.8)$ & $68.3(71.5)$ \\
\hline & & Path $3(10: 44-11: 03)$ & 500 & $34.1(36.2)$ & $6.9(8.7)$ & $0.414(0.456)$ & $23.7(25.2)$ & $72.2(75.5)$ \\
\hline & & Path 2 (11:14-11:37) & 1000 & $35.7(42.5)$ & $5.4(6.1)$ & $0.248(0.278)$ & $22.7(24.7)$ & $66.6(85.9)$ \\
\hline & & Path $3(11: 48-12: 06)$ & 1000 & $31.7(42.3)$ & $5.1(5.6)$ & $0.194(0.213)$ & $23.2(24.6)$ & $62.9(73.0)$ \\
\hline & & Path $2(12: 16-12: 36)$ & 500 & $34.5(43.4)$ & $9.1(31.5)$ & $0.296(0.916)$ & $23.7(26.3)$ & $70.0(91.6)$ \\
\hline & & Path 1 (12:48-13:06) & 1500 & $32.9(93.5)$ & $4.2(5.0)$ & $0.158(0.193)$ & $20.8(22.0)$ & $57.5(70.1)$ \\
\hline & \multirow{5}{*}{ PM } & 15:09-17:18 & & $38.8(50.9)$ & $7.7(66.4)$ & $0.187(0.509)$ & $24.0(26.9)$ & $72.5(90.8)$ \\
\hline & & Path $2(15: 09-15: 31)$ & 1000 & $35.0(40.3)$ & $9.0(32.6)$ & $0.272(0.509)$ & $22.9(23.1)$ & $75.5(77.2)$ \\
\hline & & Path $3(15: 42-15: 58)$ & 1000 & $41.7(46.1)$ & $5.6(6.2)$ & $0.157(0.173)$ & $22.6(23.8)$ & $78.1(87.8)$ \\
\hline & & Path 2 (16:10-16:32) & 500 & $33.5(37.0)$ & $10.1(66.4)$ & $0.188(0.398)$ & $25.5(26.9)$ & $66.2(72.4)$ \\
\hline & & Path $3(16: 46-17: 06)$ & 500 & $42.8(48.0)$ & $6.0(7.7)$ & $0.150(0.152)$ & $24.3(25.2)$ & $71.9(76.8)$ \\
\hline \multirow{7}{*}{ Aug. 10} & & 12:38-15:53 & & $44.0(73.4)$ & $9.1(63.4)$ & $0.258(1.736)$ & $25.3(26.9)$ & $68.1(72.7)$ \\
\hline & & Path $2(12: 38-12: 58)$ & 500 & $35.5(45.5)$ & $10.6(28.5)$ & $0.413(0.885)$ & $25.2(26.4)$ & $68.1(72.7)$ \\
\hline & & Path $3(13: 12-13: 29)$ & 500 & $43.3(48.2)$ & $5.0(5.6)$ & $0.212(0.236)$ & $24.9(25.5)$ & $69.1(70.7)$ \\
\hline & & Path $2(13: 41-14: 02)$ & 500 & $37.2(60.6)$ & $17.4(63.4)$ & $0.460(1.736)$ & $25.3(26.6)$ & $68.2(71.3)$ \\
\hline & & Path $3(14: 15-14: 36)$ & 500 & $44.4(57.3)$ & $4.4(5.5)$ & $0.162(0.198)$ & $25.0(25.3)$ & $69.3(71.4)$ \\
\hline & & Path $2(14: 48-15: 08)$ & 500 & $39.5(49.4)$ & $16.5(59.0)$ & $0.261(0.915)$ & $25.6(26.4)$ & $68.3(72.1)$ \\
\hline & & Path $3(15: 21-15: 41)$ & 500 & $40.0(59.2)$ & $3.5(4.8)$ & $0.152(0.165)$ & $24.5(25.9)$ & $67.3(68.9)$ \\
\hline
\end{tabular}


Table 5. Summary of aircraft measurement data during the sampling period(II).

\begin{tabular}{|c|c|c|c|c|c|c|}
\hline \multicolumn{2}{|c|}{ Flight date } & Flight time & $\begin{array}{l}\text { VOCs }(\mathrm{ppb}) \\
\text { mean }(\max )\end{array}$ & $\begin{array}{l}\text { PAN (ppb) } \\
\text { mean (max) }\end{array}$ & $\begin{array}{l}\mathrm{HNO}_{3}(\mathrm{ppb}) \\
\text { mean }(\max )\end{array}$ & $\begin{array}{l}\mathrm{SO}_{4}{ }^{2-}(\mathrm{ppb}) \\
\text { mean }(\max )\end{array}$ \\
\hline Jun. 1 & & $13: 29-15: 20$ & $39.8(64.9)$ & - & - & - \\
\hline \multirow{2}{*}{ Jun. 5} & $\mathrm{AM}$ & $10: 37-12: 27$ & $61.2(127.1)$ & - & - & - \\
\hline & PM & $14: 42-16: 25$ & $23.8(33.9)$ & - & - & - \\
\hline Jul. 30 & & $13: 28-15: 14$ & $65.2(130.2)$ & $0.6(1.0)$ & $2.7(27.9)$ & $1.9(5.5)$ \\
\hline Aug. 4 & & $13: 22-16: 35$ & $30.1(54.4)$ & $0.4(0.9)$ & $0.8(2.0)$ & $2.0(5.3)$ \\
\hline Aug. 5 & & $12: 47-15: 51$ & $38.7(79.1)$ & $0.2(0.4)$ & $2.7(5.4)$ & $3.1(7.4)$ \\
\hline Aug. 8 & & $14: 41-16: 55$ & $66.7(93.9)$ & $0.3(1.0)$ & $3.2(38.2)$ & $1.1(7.8)$ \\
\hline \multirow{2}{*}{ Aug. 9} & $\mathrm{AM}$ & $10: 10-13: 06$ & $75.4(324.1)$ & $0.2(0.3)$ & $1.3(4.3)$ & $1.4(3.8)$ \\
\hline & PM & $15: 09-17: 18$ & $34.7(74.8)$ & $0.1(0.5)$ & $1.0(7.1)$ & $1.4(5.3)$ \\
\hline Aug. 10 & & $12: 38-15: 53$ & $56.2(166.1)$ & $0.2(0.4)$ & - & - \\
\hline
\end{tabular}

concentration of $\mathrm{NO}_{\mathrm{y}}$ ranged from 6.7 to $24.2 \mathrm{ppb}$, lower than the values found by ground measurement (NIER 2010), and reached $125.6 \mathrm{ppb}$ on August 1. The CO concentration ranged from 0.152 to 0.487 ppm on average. On August 9, however, it reached $2.138 \mathrm{ppm}$, its highest value. In general, the concentrations of $\mathrm{O}_{3}$ and $\mathrm{CO}$ increased at higher locations. High concentrations were observed along Path 2, below which industrial facilities are located.

Unlike ozone, VOCs could not be measured consecutively. Thus, one to three samples collected from each path were analyzed. The VOC measurements were described as the sum of the individually-measured VOCs. The daily mean value ranged from 23.8 to $75.4 \mathrm{ppb}$ during the aerial observation period. During the morning flight on August 9, the concentration was observed to be $324.1 \mathrm{ppb}$, its highest value. Similar to the $\mathrm{NO}_{\mathrm{y}}$ and $\mathrm{CO}$ measurements, the VOC concentrations measured for the Path 2 samples, taken above a cluster of petrochemical industrial complexes, were generally the highest. Measuring PAN, $\mathrm{HNO}_{3}$, and $\mathrm{SO}_{4}{ }^{2-}$ with an autosampler showed that the mean concentration of PAN was $0.3 \mathrm{ppb}$, similar to the value measured on the ground at Myodo (0.28 ppb). During the observation period, the mean concentration of $\mathrm{HNO}_{3}$ was $2.0 \mathrm{ppb}$, higher than the mean value measured on the ground $(0.16 \mathrm{ppb}$, NIER 2010).

\section{3 Concentration of Ozone and Its Precursors in Each Area (by Altitude and Latitude)}

To look into the spatial distribution of $\mathrm{O}_{3}, \mathrm{NO}_{\mathrm{y}}$, and $\mathrm{CO}$ concentrations measured by aerial observation, the entire data are shown according to altitude and latitude in Fig. 4. The measurements were performed between altitudes of 500 and $1,500 \mathrm{~m}$. Paths 2 and 3 were compared using data from $500 \mathrm{~m}$ and $1,000 \mathrm{~m}$. Path 1, which had geographical restrictions, had no data for $500 \mathrm{~m}$, so the data for $1,000 \mathrm{~m}$ and $1,500 \mathrm{~m}$ were compared with the $1,000 \mathrm{~m}$ data from other paths.

The concentration distribution of each altitude was found as follows: At the altitude of $500 \mathrm{~m}$, Path 3, located above the sea, showed higher values in both median and maximum $\mathrm{O}_{3}$ concentrations than Path 2 . The concentrations of $\mathrm{NO}_{\mathrm{y}}$ and $\mathrm{CO}$, on the other hand, were higher on Path 2, above densely-located major emission sources. At the altitude of $1,000 \mathrm{~m}$, Paths 2 and 3 showed similar $\mathrm{O}_{3}$ concentrations. Compared with Paths 2 and 3, Path 1 showed lower median $\mathrm{O}_{3}$ concentrations but more frequent highozone episodes. The $\mathrm{NO}_{\mathrm{y}}$ concentrations showed a distributional pattern similar to ozone, but the $\mathrm{CO}$ concentrations were distributed in the opposite pattern. Considering that there were no specific emission sources below Path 1, it is assumed that the high concentrations in this area were attributable to ozone precursors and ozone transported by sea breeze during the day or to ozone produced by forest areas.

As with concentration by altitude, both Paths 2 and 3 showed that the median ozone concentrations at the altitude of 1,000 m were slightly higher than those at $500 \mathrm{~m}$. But at the altitude of $500 \mathrm{~m}$, values greater than the 90th percentile were observed more often and were more widely distributed with varied ozone concentrations. At this altitude, maximum ozone concentrations also occurred more frequently. In Paths 2 and 3 , both median and maximum values of $\mathrm{NO}_{\mathrm{y}}$ concentrations were found more often at $1,000 \mathrm{~m}$. $\mathrm{NO}_{\mathrm{y}}$ generated from emission sources seems to display a distributional pattern different than that of ozone. It may be necessary to conduct additional studies on $\mathrm{NO}_{\mathrm{y}}$ transport and distribution using models.

\subsection{Analysis of $\mathrm{O}_{3}$ Spatial Distribution by Case}

\section{4. 1 Days of High Ozone Concentrations}

The three-dimensional distribution of $\mathrm{O}_{3}$ concentrations is usually presented in a manner that demon- 

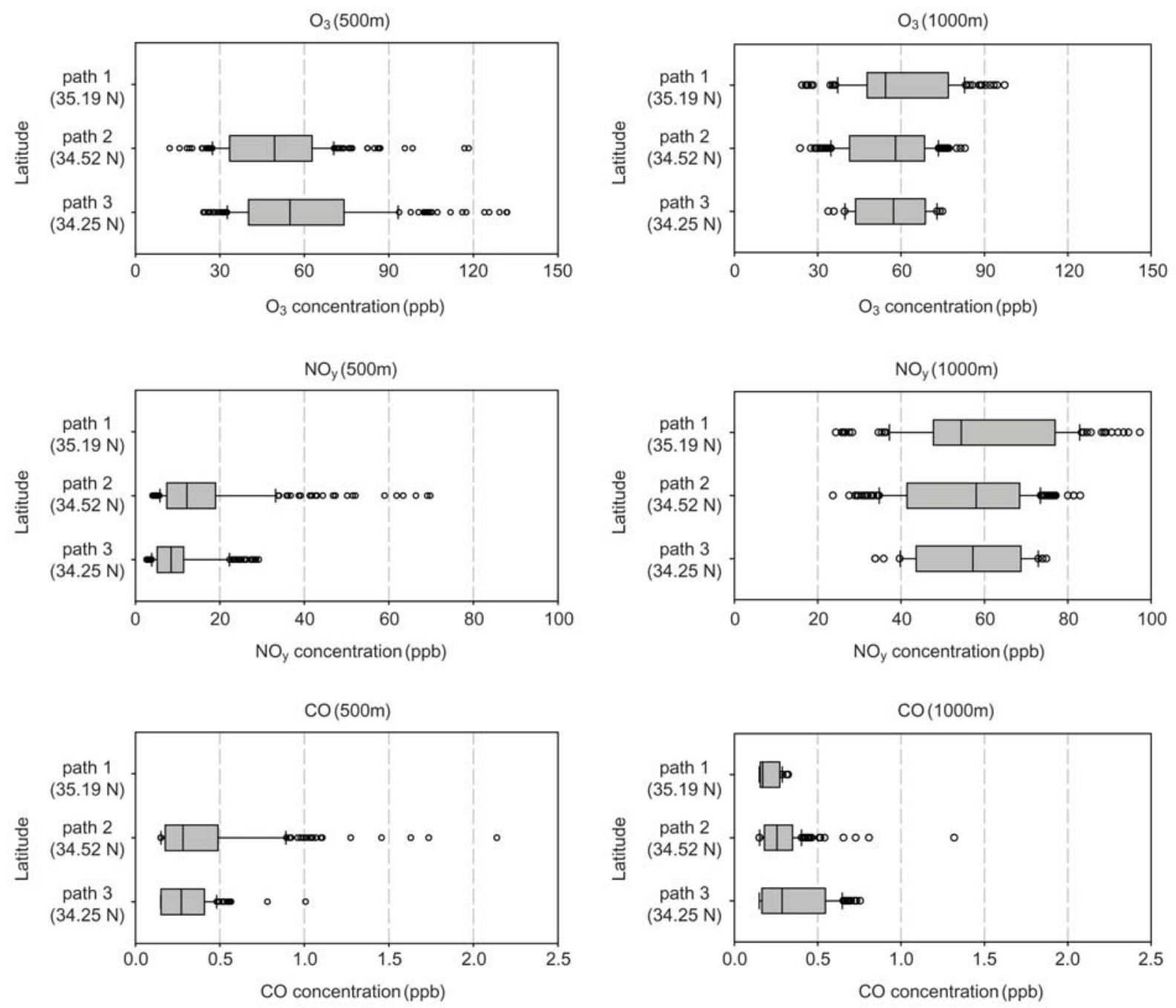

Fig. 4. Latitudinal and altitudinal distributions of $\mathrm{O}_{3}, \mathrm{NO}_{\mathrm{y}}$ and $\mathrm{CO}$ concentrations.

strates the appearance and disappearance of ozone, as well as the transportation of ozone and its precursors. The $\mathrm{O}_{3}$ concentration is often higher altitude in the air than on the ground. This study found that there were five days during the period of aerial measurement when the $\mathrm{O}_{3}$ concentration in the high altitude was over $100 \mathrm{ppb}$. On the ground, however, the number of days with $\mathrm{O}_{3}$ concentrations over $100 \mathrm{ppb}$ was three. The mean $\mathrm{O}_{3}$ concentration in the high altitude during the aerial measurement period was $60.5 \mathrm{ppb}$, significantly higher than that measured on the ground at Myodo (34 ppb).

To analyze the days when high $\mathrm{O}_{3}$ concentrations were observed, the measurements of June 1 and July 31 were studied.

On June 1 , the highest mean $\mathrm{O}_{3}$ concentration was recorded during the flight period. It was sunny with a strong wind from the southwest, which was largely influenced by a high pressure area over the sea south of Jeju Island. Fig. 5 shows the aerial measurement paths and wind roses provided by the meteorological offices. The aerial measurements were conducted over five paths from 13:29 to 15:20.

In the southernmost area of Yeosu, the mean $\mathrm{O}_{3}$ concentration was $90.8 \mathrm{ppb}$ and the highest $\mathrm{O}_{3}$ concentration was $132 \mathrm{ppb}$. The mean $\mathrm{NO}_{\mathrm{y}}$ concentration was $24.2 \mathrm{ppb}$, while the mean concentrations of $\mathrm{CO}$ and TVOCs were $0.487 \mathrm{ppb}$ and $39.8 \mathrm{ppb}$, respectively.

Fig. 6 displays a time-series comparison between Path 2 and Path 4 to show the change in ozone and its precursors along the aerial paths. The mean $\mathrm{O}_{3}$ concentrations on these paths were $83.2 \mathrm{ppb}$ and 109.7 $\mathrm{ppb}$, respectively. The $\mathrm{O}_{3}$ concentration in the south- 


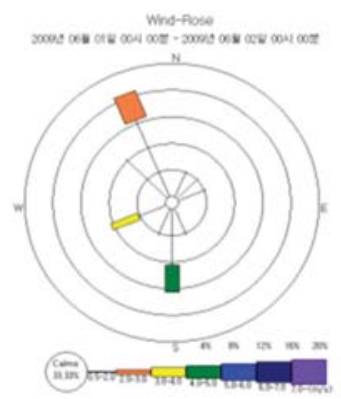

Suncheon meteorological office

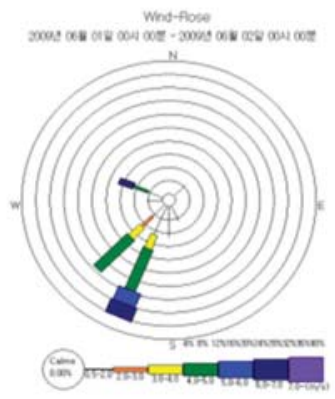

Yeosu

meteorological office

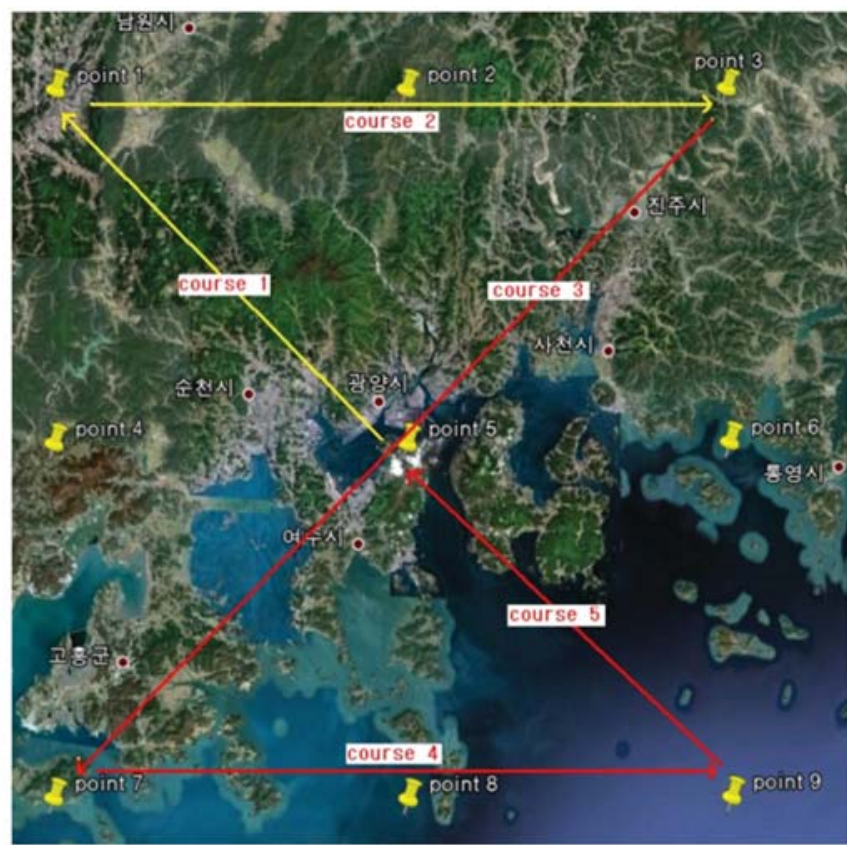

Flight paths for aerial measurement on June $1^{\text {st }}$
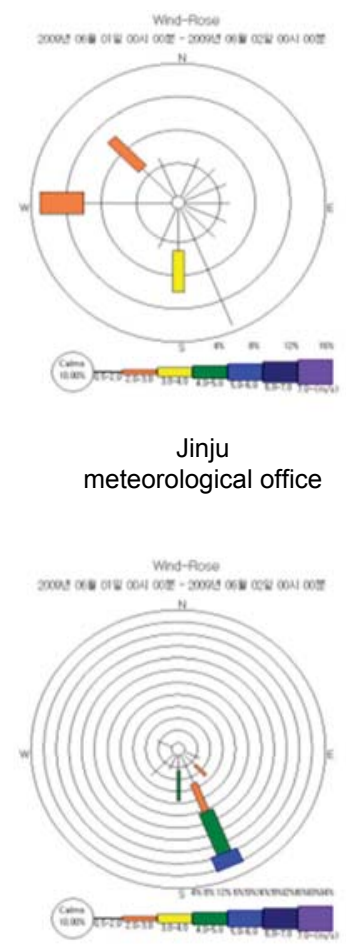

Tongyeong meteorological office

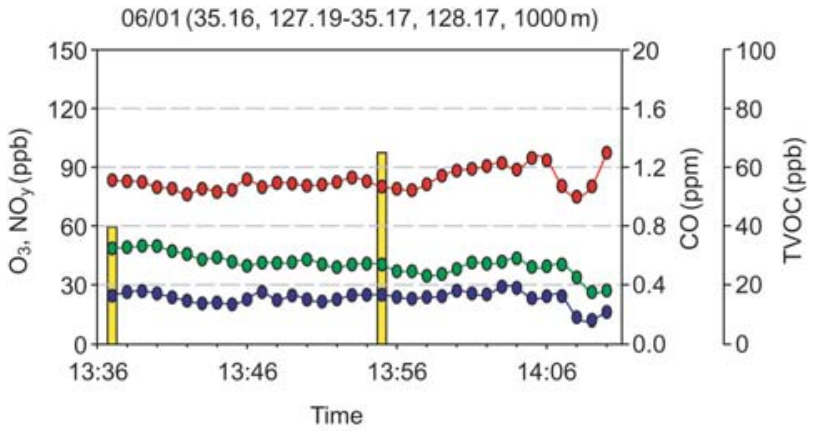

Path 2 (Altitude $1000 \mathrm{~m}$ )

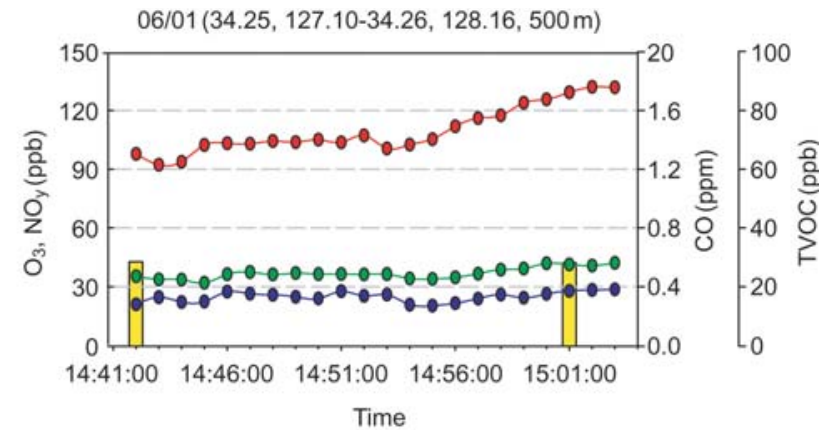

Path 4 (Altitude $500 \mathrm{~m}$ )

$$
\square \text { TVOC } \rightarrow \mathrm{NO}_{\mathrm{y}}(\mathrm{ppb}) \multimap \mathrm{O}_{3}(\mathrm{ppb}) \multimap \mathrm{CO}(\mathrm{ppm})
$$

Fig. 6. Variation in $\mathrm{O}_{3}, \mathrm{NO}_{\mathrm{y}}, \mathrm{CO}$ and TVOC concentrations measured in Paths 2 and 4.

ernmost part of Yeosugrew steadily over time and was highest at the end of the path.

On June 1, the maximum $\mathrm{O}_{3}$ concentration measured at the ground monitoring stations also exceeded $100 \mathrm{ppb}$. The $\mathrm{O}_{3}$ concentrations measured in Gwangyang and Jinju, both of which are located in the north, were higher than in Yeosu. The highest concentration was measured between 14:00 and 15:00. The concentrations measured at monitoring stations in the northern area rose over time.

Fig. 7 shows $\mathrm{O}_{3}$ concentrations and ground wind fields measured by the ground monitoring stations, as 


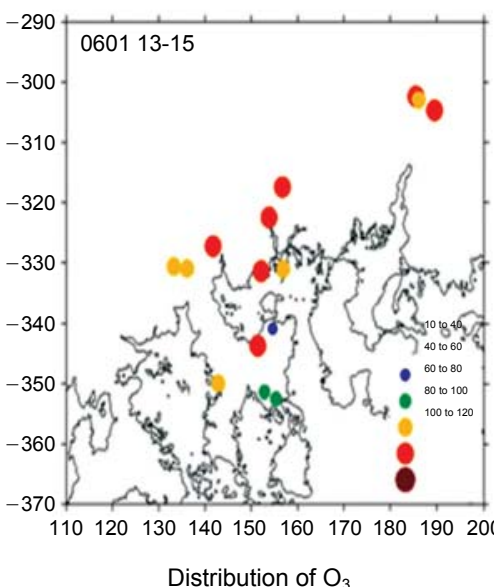

concentration measure by ground monitoring stations

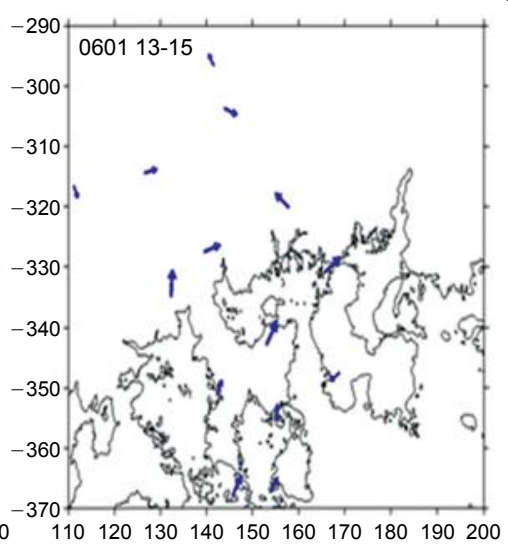

Wind fields measured by ground stations
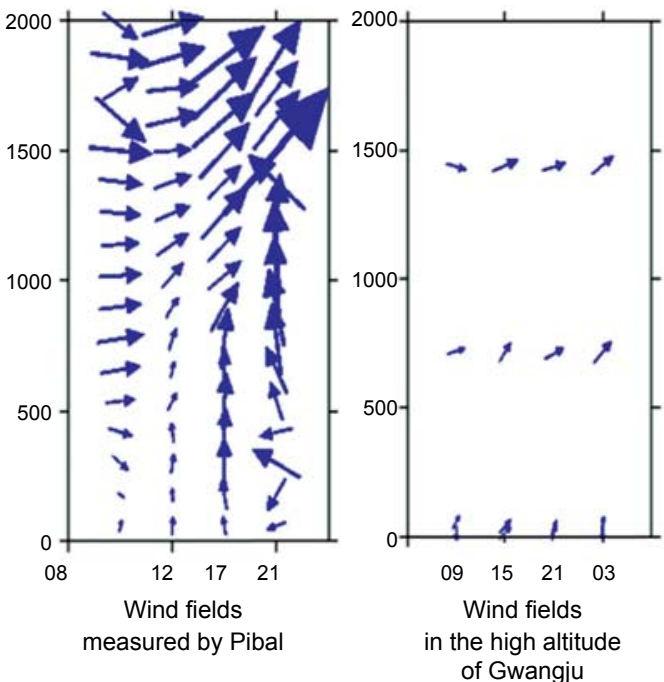

Fig. 7. Ozone concentration measured by urban air quality monitoring stations and wind fields of vertical profile and ground.

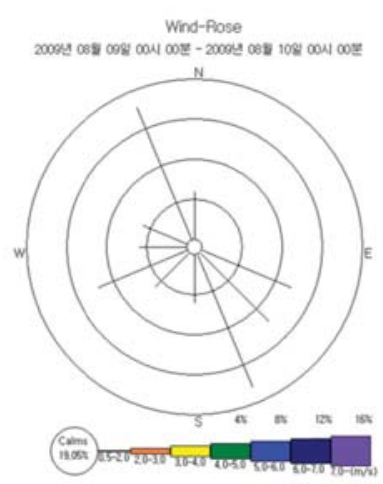

Suncheon meteorological office

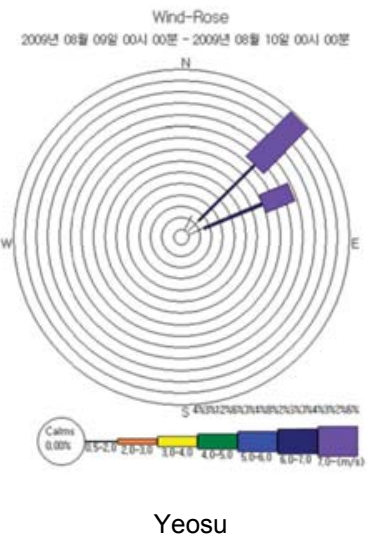

meteorological office

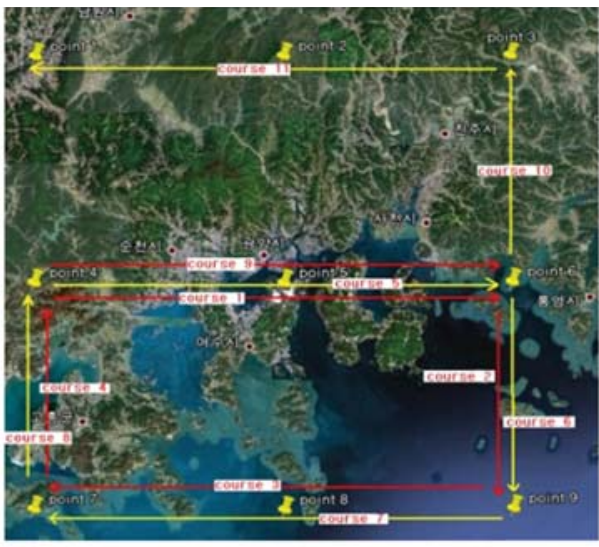

Flight paths for aerial measurement on August 9 AM

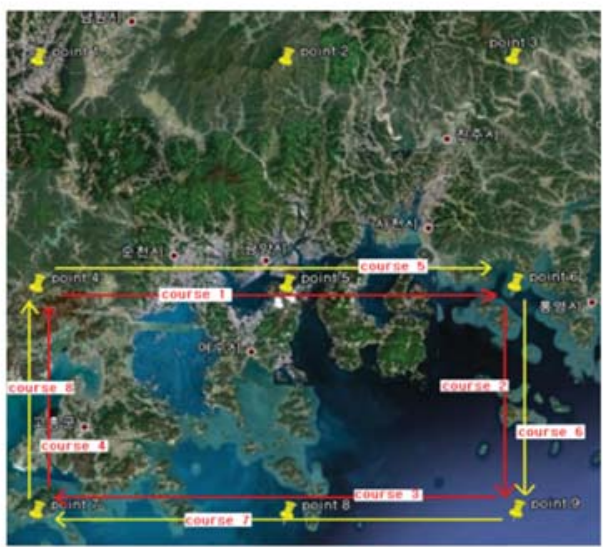

Flight paths for aerial measurement on August 9 PM
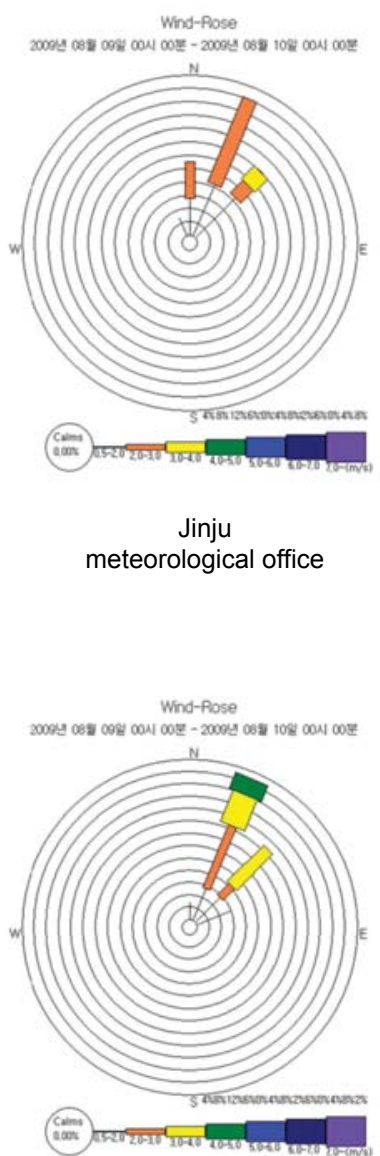

Tongyeong meteorological office

Fig. 8. Aerial measurement paths and wind roses on August $9^{\text {th }}$. 

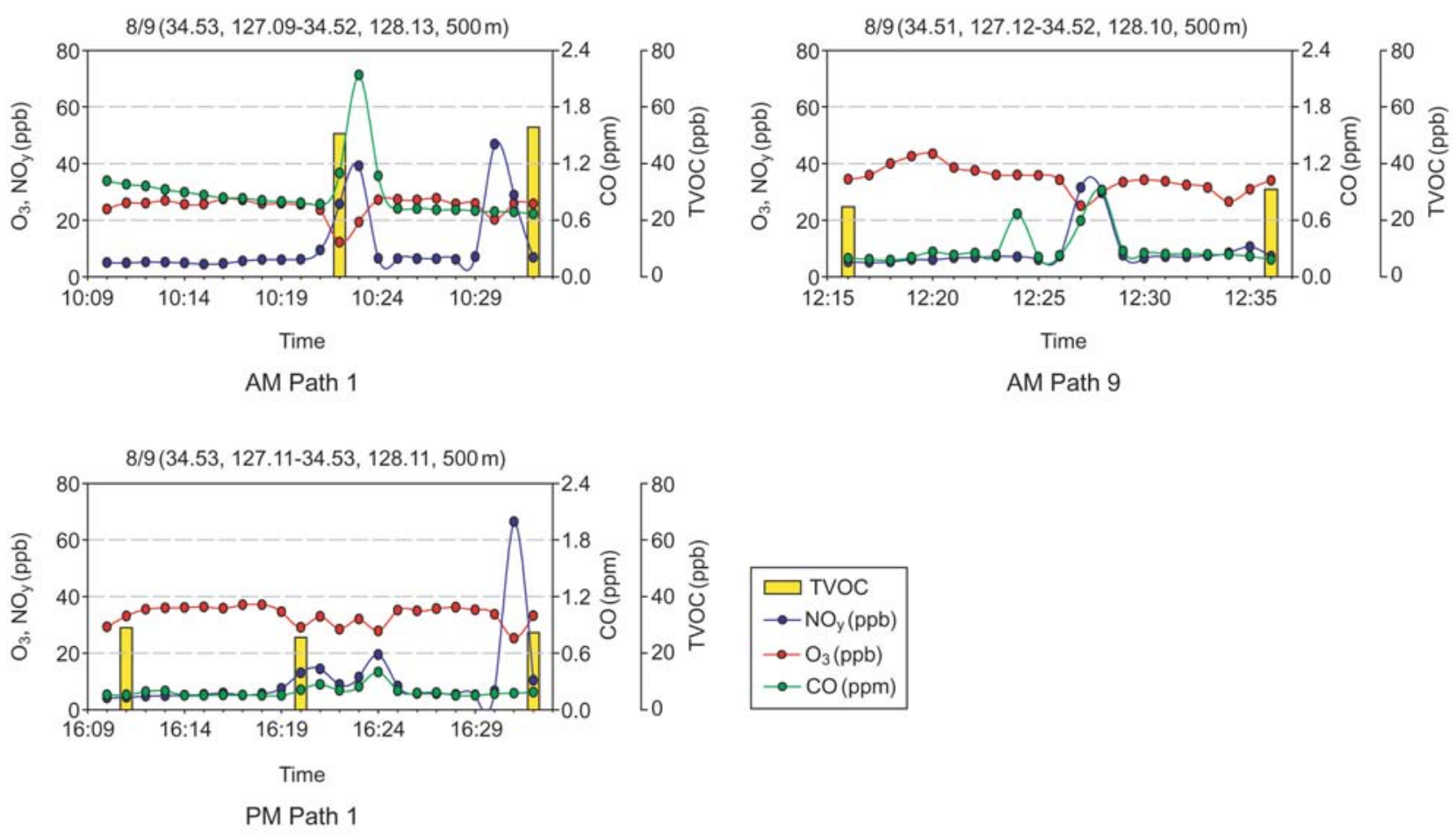

Fig. 9. Variation in concentrations of $\mathrm{O}_{3}, \mathrm{NO}_{\mathrm{y}}, \mathrm{CO}$ and TVOCs measured in Paths 1 and 9 at AM and Path 1 at PM.

well as the wind field for each altitude, and wind fields in the high altitude Gwangju measured by the pibal (pilot balloon). The wind on the ground and at each altitude was found to blow mainly from the south. Based on the aerial observation results, ground monitoring, and wind field measurements, we assumed that the highly-concentrated ozone generated by the sea over the southernmost end of Yeosu, and the ozone formed in the neighboring area of Gwangyang Bay moved northward with the winds, thereby contributing to the growing $\mathrm{O}_{3}$ concentrations observed over time by the ground monitoring stations in the northern area.

Analysis of the high ozone concentrations on June 1 showed the following ozone distributional characteristics across Gwangyang Bay: First, the $\mathrm{O}_{3}$ concentrations in the high altitude marine areas were high compared to inland areas. Second, it is assumed that the ozone precursors, which originated in the industrial complexes of Gwangyang Bay, generated ozone as they moved with the wind. Last, the generated ozone moved in the form of a plume with the wind to affect the ground. Ozone was generated, destroyed, or transported in response to the weather conditions of the day to influence conditions on the ground. Aerial measurement results showed that the high concentrations of ozone generated in coastal or marine areas decreased as the ozone plumes moved with the wind.

\section{4. 2 Days of Low Ozone Concentrations}

On August 9, aerial measurements were conducted in the morning and afternoon. Fig. 8 shows aerial measurement paths and wind roses. The main aerial paths were set based on latitude. The outstanding wind direction on the ground was northeast from inland.

The flight was made three times at an altitude of 500 meters over the aerial paths: twice in the morning, and once in the afternoon. The aerial paths are comparable to the paths $\left(34^{\circ} 52^{\prime} \mathrm{N}\right.$ and $127^{\circ} 10^{\prime} \mathrm{E}$ to $128^{\circ}$ $\left.15^{\prime} \mathrm{E}\right)$ in Gwangyang Bay.

These measurements indicated that the $\mathrm{O}_{3}$ concentration fell to between 20 and $35 \mathrm{ppb}$. The concentrations of $\mathrm{NO}_{\mathrm{y}}$ and $\mathrm{CO}$ were about $10 \mathrm{ppb}$ and $0.6 \mathrm{ppm}$, respectively, while their maximum concentrations were relatively high: $46.8 \mathrm{ppb}$ and $2.138 \mathrm{ppm}$. The time-series distribution of the measurements is shown in Fig. 9.

The flight over Path 1 in the morning observed high concentrations of $\mathrm{NO}_{\mathrm{y}}$ and $\mathrm{CO}$ in the high altitude Gwangyang Bay, indicating the same trend as seen for high concentrations. The morning flight over Path 9 also found rising concentrations of $\mathrm{NO}_{\mathrm{y}}$ and $\mathrm{CO}$. An increase in $\mathrm{O}_{3}$ concentration, however, was not observ- 
Table 6. Ozone concentrations measured by urban air quality monitoring stationson August $9^{\text {th }}$.

(Unit: ppb)

\begin{tabular}{|c|c|c|c|c|c|c|c|c|}
\hline \multirow{2}{*}{ Time } & \multicolumn{4}{|c|}{ Gwangyang } & \multicolumn{4}{|c|}{ Yeosu } \\
\hline & Jeong-dong & Jinsang-myeon & Chilseong-ri & Taein-dong & Gwangmu-dong & Munsu-dong & Samil-dong & Wollae-dong \\
\hline $10: 00$ & 20.0 & 18.0 & 19.0 & 20.0 & 14.0 & 19.0 & 22.0 & 22.0 \\
\hline $15: 00$ & 28.0 & 28.0 & 29.0 & 28.0 & 25.0 & 31.0 & 30.0 & 32.0 \\
\hline
\end{tabular}

ed: it remained at $40 \mathrm{ppb}$ or less. The temperature was high: the maximum temperature measured at the meteorological offices was $29.7^{\circ} \mathrm{C}$. A high temperature, when combined with solar radiation, usually creates good conditions for generating high $\mathrm{O}_{3}$ concentrations in the afternoon. But the result of the measurement after 16:00 showed that the ozone concentration did not rise above $40 \mathrm{ppb}$. The measurements from the ground monitoring stations (Table 4) also indicate that the $\mathrm{O}_{3}$ concentration remained around $30 \mathrm{ppb}$.

Compared to the high concentration cases, the air temperatures and $\mathrm{O}_{3}$ precursor concentrations were similar, while the $\mathrm{O}_{3}$ concentrations were lower. This may be attributable to various reasons, but it is assumed that weather conditions, such as wind direction and speed, had a strong influence on the differences in ozone concentration. On August 9, the wind speed was measured at $2.6 \mathrm{~m} / \mathrm{s}$, higher than seen on the other days.

\section{CONCLUSIONS}

Measuring $\mathrm{O}_{3}$ and its precursors at the southern coast of Korea through aerial, ground, and weather observations led to the following conclusions:

* The results of aerial observation showed that the mean $\mathrm{O}_{3}$ concentration in the ranged between 32.3 and $90.8 \mathrm{ppb}$.

* The $\mathrm{O}_{3}$ concentration was slightly higher at 1,000 $\mathrm{m}$ than at $500 \mathrm{~m}$, while the maximum $\mathrm{O}_{3}$ concentrations were more frequently observed at $500 \mathrm{~m}$.

* The CO concentration, which averaged between 0.152 and $0.487 \mathrm{ppm}$, was observed to be higher in the sky above the industrial complexes and southern seas.

* The times when the highest PAN concentrations were observed were generally similar to those of high ozone concentrations. The concentrations of toluene and $m, p$-Xylene were observed to be higher, and their contributions to ozone generation were higher as well.

* During the period of aerial measurement, the number of days when the maximum $\mathrm{O}_{3}$ concentration exceed- ed $100 \mathrm{ppb}$ was five.

* Measurements of vertical wind fields in the air indicated that ozone generated in the southernmost area of Yeosu was transported by strong southwest winds to the northeastern part of Gwangyang Bay, where the $\mathrm{O}_{3}$ concentration rose to $100 \mathrm{ppb}$ or higher in Jinju.

\section{REFERENCES}

Chameides, W.L., Fehsenfeld, F., Rodgers, M.O., Cardelino, C., Martinez, J., Parrish, D., Lonneman, W., Lawson, D.R., Rasmussen, R.A., Zimmerman, P., Greenberg, J., Middleton, P., Wang, T. (1992) Ozone Precursor Relationships in the Ambient Atmosphere. Journal of Geophysical Research 97(D5): doi: 10.1029/91JD03014. issn: 0148-0227.

Cheng, W.L. (2002) Ozone Distribution in coastal central Taiwan under sea-breeze condition. Atmospheric Environment 36, 3445-3459.

Fehsenfeid, F., Calvert, J., Fall, R., Goldan, P., Guenther, A.B., Hewitt, C.N., Lamb, B., Liu, S., Trainer, M., Westberg, H., Zimmermann, P. (1992) Emission of volatile organic Compounds from Vegetation and the implication for atmospheric chemistry. Global Biogeochemical Cycles 6, 389-430.

Ha, H., Lee, S.D., Lee, J.K., Park, C.O., Mun, T.R. (2006) On Characteristics of Surface Ozone Concentration and Temporal-Spatial Distribution in Kwangyang-Bay. Journal of Korea Society for Atmospheric Environment 22(5), 642-652.

Han, J.S., Kim, Y.M., Ahn, J.Y., Kong, B.J., Choi, J.S., Lee, S.U., Lee, S.J. (2005) Spatial Distribution and Variation of Long-range Transboundary Air Pollutants Flux During 1997-2004. Journal of Korea Society for Atmospheric Environment 22(1), 99-106.

Helmig, D., Boulter, J., David, D., Birks, J.W., Cullen, N.J., Steffen, K., Johnson, B.J., Oltmans, S.J. (2002) Ozone and meteorological boundary-layer condition at Summit, Greenland, during 3-21 June 2000. Atmospheric Environment 36, 2595-2608.

Herman, J., Bharta, P., Ziemke, J., Ahmad, Z., Larko, D. (1996) UV-B increases (1979-1992) from decreases in total Ozone. Geophysical Research Letters 23, 2107 2100.

Kleinman, L.I. (2000) Ozone process insights from field experiments-Part II: Observation-based analysis for ozone production. Atmospheric Environment 39, 575- 
586.

Lee, H.W., Park, S.Y., Lee, S.H., Leem, H.H. (2009). Characteristics of Ozone Advection in Vertical Observation Analysis Around Complex Coastal Area. Journal of Korea Society for Atmospheric Environment 25(1), 57-74.

Liu, K.Y., Wang, Z., Hsiao, L.F. (2002) A modeling of the sea breeze and its impacts on ozone distribution in northern Taiwan. Environmental Modeling \& Software 17, 21-27.

National Institute of Environmental Research (2006). Study on Ozone Precursor and Meteorological Parameters During High-Ozone Episodes.

Oh, I.B., Kim, Y.K., Hwang, M.K. (2004) Effects of Late Sea-breeze on Ozone Distributions in the Coastal Urban Area. Journal of Korea Society for Atmospheric Environment 20(3), 345-360.

Papayannis, D., Bali, D., Bais, A., Calpin, B., Durieux,
E., Fiorain., L., Jaquet, L., Ziomas, I., Zerefos, C.S. (1998) Role of urban and suburban aerosols on soler UV radiation over Athens, Greece. Atmospheric Environment 32(12), 2193-2201.

Seo, S.J., Kim, S.Y., Lee, M.D., Choi, J.S, Kim, S.Y., Lee, S.J., Kim, J.S., Lee, G.W. (2012) The Analysis of Spatial distribution of Ozone in the Southern coast of Korea using the aircraft (2009, Summer). Journal of Korea Society for Atmospheric Environment 28(1), 12-21.

Wang, T., Wu, Y.Y., Cheung, T.F., Lam, K.S. (2001) A study of surface ozone and the relation to complex wind flow in Hong Kong. Atmospheric Environment 23, 1812-1826.

(Received 20 June 2013, revised 9 September 2013, accepted 10 September 2013) 